The State after Statism 



\section{The State after Statism}

NEW STATE ACTIVITIES IN

THE AGE OF LIBERALIZATION

\section{Edited by \\ Jonah D. Levy}

HARVARD UNIVERSITY PRESS

Cambridge, Massachusetts

London, England 2006 
Copyright (C) 2006 by the President and Fellows of Harvard College All rights reserved

Printed in the United States of America

\section{Library of Congress Cataloging-in-Publication Data}

The state after statism : new state activities in the age of liberalization / edited by Jonah D. Levy.

p. $\mathrm{cm}$.

Papers presented at three workshops held at the University of California, Berkeley, in October 2002, May 2003, and November 2003.

Includes bibliographical references and index.

ISBN-13: 978-0-674-02276-8 (cloth : alk. paper)

ISBN-10: 0-674-02276-9 (cloth : alk. paper)

ISBN-13: 978-0-674-02277-5 (paper : alk. paper)

ISBN-10: 0-674-02277-7 (paper : alk. paper)

1. Industrial policy-Congresses. 2. Comparative economics-Congresses. 3. Economics-Political aspects-Congresses. 4. State, TheCongresses. I. Levy, Jonah D.

HD3611.S755 2006

$330.12^{\prime} 6$ - dc22 2006041101 
To Julien, Elijah, and Charlotte who have taught me the joys of new missions and responsibilities 
